\title{
Specific functions of Exostosin-like 3 (EXTL3) gene products
}

Shuhei Yamada(1)

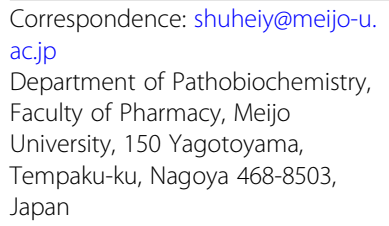

Correspondence: shuheiy@meijo-u. ac.jp

Department of Pathobiochemistry, Faculty of Pharmacy, Meijo University, 150 Yagotoyama, Tempaku-ku, Nagoya 468-8503, Japan

\begin{abstract}
Exostosin-like 3 (EXTL3) encodes the glycosyltransferases responsible for the biosynthesis of the backbone structure of heparan sulfate (HS), a sulfated polysaccharide that is ubiquitously distributed on the animal cell surface and in the extracellular matrix. A lack of EXTL3 reduces HS levels and causes embryonic lethality, indicating its indispensable role in the biosynthesis of HS. EXTL3 has also been identified as a receptor molecule for regenerating islet-derived (REG) protein ligands, which have been shown to stimulate islet $\beta$-cell growth. REG proteins also play roles in keratinocyte proliferation and/or differentiation, tissue regeneration and immune defenses in the gut as well as neurite outgrowth in the central nervous system. Compared with the established function of EXTL3 as a glycosyltransferase in HS biosynthesis, the REG-receptor function of EXTL3 is not conclusive. Genetic diseases caused by biallelic mutations in the EXTL3 gene were recently reported to result in a neuro-immuno-skeletal dysplasia syndrome. EXTL3 is a key molecule for the biosynthesis of HS and may be involved in the signal transduction of REG proteins.

Keywords: Exostosin-like 3 (EXTL3), Heparan sulfate (HS), Biosynthesis, Glycosaminoglycan, Regenerating islet-derived (REG) protein
\end{abstract}

\section{Introduction}

Hereditary multiple exostosis (HME), also known as multiple osteochondromas, is a rare disorder occurring in approximately 1 in 50,000 individuals [1, 2]. It is characterized by cartilaginous or bony tumors, called osteochondromas or exostoses, which form within the perichondrium flanking the growth plates of the long bones, vertebrae, ribs and cranial base [3].

Previous studies on the genetic linkage for this disease reported some loci on the chromosomes, with mutation analyses identifying two genes as tumor suppressors: exostosin 1 (EXT1) and exostosin 2 (EXT2) [4-6]. Functional analyses showed that these genes encode the glycosyltransferases responsible for the biosynthesis of the backbone structure of heparan sulfate (HS), a sulfated polysaccharide that is ubiquitously distributed on the animal cell surface and in the extracellular matrix $[7,8]$. Screening for proteins homologous to EXT1 and EXT2 identified the EXT-like proteins, EXTL1, EXTL2 and EXTL3, which are members of the EXT family (Table 1) [10-12]. These EXT-like proteins are also glycosyltransferases, and at least EXTL3 can

(c) The Author(s). 2020 Open Access This article is licensed under a Creative Commons Attribution 4.0 International License, which permits use, sharing, adaptation, distribution and reproduction in any medium or format, as long as you give appropriate credit to the original author(s) and the source, provide a link to the Creative Commons licence, and indicate if changes were made. The images or other third party material in this article are included in the article's Creative Commons licence, unless indicated otherwise in a credit line to the material. If material is not included in the article's Creative Commons licence and your intended use is not permitted by statutory regulation or exceeds the permitted use, you will need to obtain permission directly from the copyright holder. To view a copy of this licence, visit http://creativecommons.org/licenses/by/4.0/. 
Table 1 Human EXT family

\begin{tabular}{|c|c|c|c|c|c|}
\hline Gene & $\begin{array}{l}\text { Chromosomal } \\
\text { location }\end{array}$ & $\begin{array}{l}\text { Amino } \\
\text { acid }\end{array}$ & $\begin{array}{l}\text { Sequence identity } \\
\text { with EXTL3 (\%) [9] }\end{array}$ & $\begin{array}{l}\text { mRNA accession } \\
\text { number }\end{array}$ & $\begin{array}{l}\text { MIM } \\
\text { number }\end{array}$ \\
\hline EXT1 & $8 q 24.11$ & 746 & 26 & NM_000127 & $\begin{array}{l}133,700 \\
215,300 \\
608,177\end{array}$ \\
\hline EXT2 & $11 p 11.2$ & 751 & 29 & NM_000401 & $\begin{array}{l}133,701 \\
608,210 \\
616,682\end{array}$ \\
\hline EXTL1 & 1p36.11 & 676 & 23 & NM_004455 & 601,738 \\
\hline EXTL2 & $1 \mathrm{p} 21.2$ & 330 & 26 & NM_001439 & 602,411 \\
\hline EXTL3 & $8 p 21.1$ & 919 & - & NM_001440 & $\begin{array}{l}605,744 \\
617,425\end{array}$ \\
\hline
\end{tabular}

catalyze the chain elongation reactions of HS polysaccharides [13, 14]. Although their involvement in HME has not yet been reported, some genetic disorders and traits related to these genes have been updated on OMIM (Online Mendelian Inheritance in Man). Table 1 shows the MIM (Mendelian Inheritance in Man) numbers of the EXT family.

This review focuses on EXTL3, a critical enzyme for the biosynthesis of HS polysaccharides. A novel function for EXTL3 as a receptor for regenerating islet-derived (REG) proteins is also discussed and congenital diseases caused by mutations in the human EXTL3 gene are described.

\section{Structure and functions of HS}

HS is a linear polysaccharide composed of an alternating repeat of D-glucuronic acid (GlcA) and $N$-acetyl D-glucosamine (GlcNAc): -4GlcA 1 1-4GlcNAc 1 1-. The amino group of the GlcNAc residue can be sulfated instead of acetylated. Some GlcA residues are C5-epimerized into iduronic acid (IdoA) residues. Hydroxy groups at the C6 position of GlcNAc/2-N-sulfated D-glucosamine and the $\mathrm{C} 2$ position of GlcA/IdoA may also be sulfated. A rare sulfation reaction occurs at the hydroxy group of the C3 position of $2-\mathrm{N}$-sulfated/2- $\mathrm{N}$-unsubstituted glucosamine residue. These modifications provide structural diversity in HS chains (Fig. 1a), which contributes to their versatile functions, including the regulation of cell proliferation, cell differentiation and cell-cell recognition through interactions with bioactive proteins, such as growth factors, morphogens, cytokines, coagulation factors, proteases and extracellular matrix molecules $[15,16]$.

\section{Biosynthetic enzymes of HS}

The biosynthesis of HS (Fig. 1b) is initiated by the xylosyltransferase-mediated transfer of a xylose (Xyl) residue from uridine diphosphate-xylose (UDP-Xyl) to a specific serine residue on a core protein [17]. Two galactose (Gal) residues are consecutively transferred from UDP-Gal to Xyl and Gal-Xyl on the core protein by galactosyltransferases I and II, respectively, to form a Gal-Gal-Xyl-core protein structure. The GlcA residue is transferred as the 4th sugar residue from UDP-GlcA by glucuronyltransferase I to form the so-called linkage tetrasaccharide region, GlcA-Gal-Gal-Xyl. The first GlcNAc residue is then transferred to the GlcA residue on this tetrasaccharide by the enzyme activity of GlcNAc transferase I from UDP-GlcNAc. GlcA transferase II and GlcNAc 


\section{A}

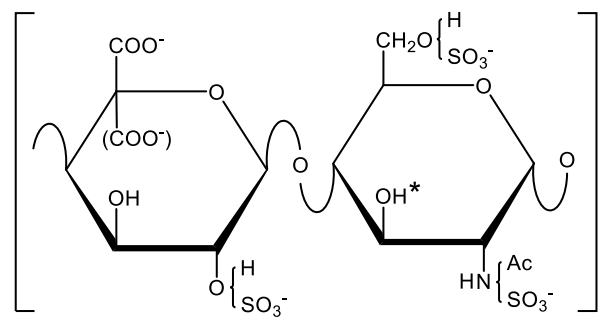

B

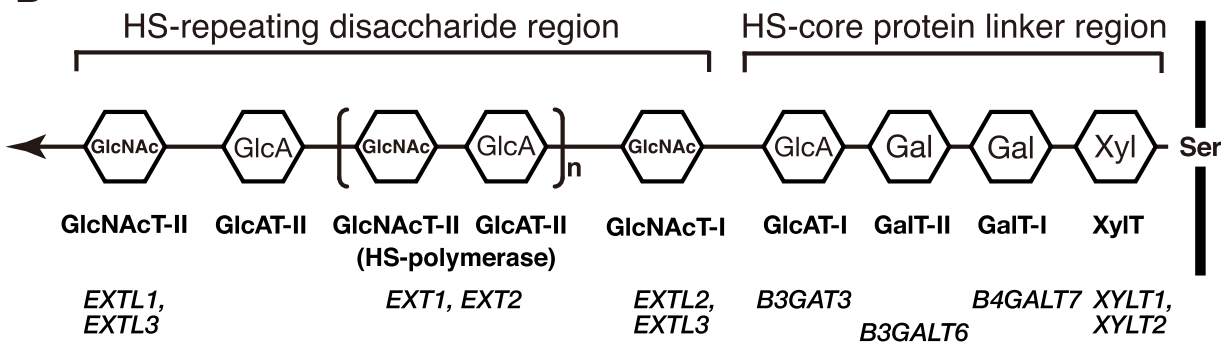

Fig. 1 Structure and biosynthesis of HS. a - The structure of the repeating disaccharide unit in HS. The polysaccharide backbone of HS is composed of an alternating repeat of GlcA/ldoA and D-glucosamine (GlcN): -4GlcAß/ldoAa1-4GlcNa1-. The amino group of GlcN is acetylated or sulfated. Hydroxy groups at the C6 of GlcN and the C2 of GlcA/IdoA may be sulfated. The hydroxy group of the C3 position (indicated by an asterisk) of $\mathrm{N}$-sulfated/N-unsubstituted GICN residue in specific saccharide sequences is possibly sulfated. b - A schematic drawing of the structure of HS polysaccharides. The enzyme responsible for the transfer of each monosaccharide residue is shown below the corresponding sugar residue. Gene(s) encoding each enzyme are also shown below. The arrow indicates the direction of biosynthesis. XylT, xylosyltransferase; GalT-I, galactosyltransferase I; GalT-II, galactosyltransferase II; GlcAT-I, glucuronyltransferase I; GlcAT-II, glucuronyltransferase II; GICNAcT-I, GICNAc transferase I; GlcNAcT-II, GlcNAc transferase II

transferase II are respectively responsible for the transfer of GlcA and GlcNAc residues from UDP-sugar donors to form the repeating disaccharide region of HS, from the 6th sugar residue to the non-reducing end. This critical reaction to form HS polymers is catalyzed by the bifunctional enzymes, HS polymerases, which exhibit the activities of GlcA transferase II and GlcNAc transferase II [7]. HS polymerases are encoded by the EXT1 and EXT2 genes.

The EXT1 and EXT2 proteins form a hetero-oligomeric complex in vitro that leads to the accumulation of both proteins in the Golgi to exhibit stronger activities than monomer proteins $[18,19]$. EXTL1, EXTL2 and EXTL3 also exhibit glycosyltransferase activities that are involved in the biosynthesis of HS. EXTL1 exhibits the enzymatic activity of GlcNAc transferase II, but is not an indispensable enzyme for the biosynthesis of HS [13]. Although other EXT family members are ubiquitously expressed in the human body and HS is systemically distributed, the expression of EXTL1 is restricted to the brain, liver and kidneys [20]. EXTL2 has been identified as the GlcNAc transferase I for HS biosynthesis in vitro [14]. However, it does not appear to be involved in the chain elongation of HS polysaccharides in vivo, but rather in the chain termination of HS because the knockdown of EXTL2 increases the total amount of HS [21].

The enzymatic activity of EXTL3 was previously demonstrated to be that of GlcNAc transferases I and II using a recombinant protein [13]. Based on gene-silencing and overexpression experiments using mammalian cells, the in vivo activity of GlcNAc 
transferase I only appears to involve EXTL3. Overexpression of EXTL3 does not affect HS chain elongation [22]. By contrast, gene knockdown with EXTL3 siRNA resulted in an increased HS chain length [22], suggesting that when less acceptor substrate is available for HS polymerization, longer HS chains form. In addition, the activity of GlcNAc transferase II of EXTL3 was weaker than those of EXT1, EXT2 and the EXT1/EXT2 complex [22]. Recently, a large panel of Chinese hamster ovary cells with knockout or knock-in of the genes encoding most of the enzymes involved in glycosaminoglycan biosynthesis was engineered to generate a library of isogenic cell lines [23]. HS levels dramatically decreased in the Chinese hamster ovary cells with knockout of EXTL3. Therefore, EXTL3 seems to be responsible for initiating the chain elongation of HS polysaccharides. As with EXT1 and EXT2, the lack of EXTL3 leads to embryonic lethality, possibly because of failed HS biosynthesis [24].

It has also been reported that EXTL3 may control the modification of glucosamine residues in HS by regulating the activity of $N$-deacetylase/ $N$-sulfotransferase- 1 (NDST1 ), which catalyzes the $N$-deactylation and $N$-sulfation of GlcNAc residues in HS [25, 26]. The formation of a complex between EXTL3 and NDST-1 reduces the $N$-sulfotransferase activity of NDST-1, but not its $\mathrm{N}$-deacetylase activity, contributing to the generation of $\mathrm{N}$-unsubstituted glucosamine residues in HS [27]. This structure shows an inhibitory effect on HS degradation against heparanase, which is a HS-specific hydrolase involved in HS catabolism. The exact function of EXTL3 in HS biosynthesis is still unclear.

\section{Characteristics of the EXTL3 protein}

The EXTL3 protein is composed of 919 amino acids, making it the longest member of the EXT family [9]. Percentage homologies between the amino acid sequence of human EXTL3 and those of human EXT1, EXT2, EXTL1 and EXTL2 were previously shown to be 26, 29, 23, and 26\%, respectively (Table 1) [9]. EXTL3 is conserved from the common ancestor of all eumetazoans [9]. It is a type II transmembrane protein composed of a short cytoplasmic region, a transmembrane region, and a long Golgi luminal region, which has two glycosyltransferase domains (Fig. 2). The GlcA transferase II activity of EXTL3 has not yet been reported. It has been shown to exhibit GlcNAc transferase I and II activities. Since the glycosyltransferase domain on the N-terminal side (GT47) of EXT1/EXT2 was predicted to be GlcA transferase II, based on a bioinformatics analysis [32], the GT47 domain of EXTL3 may exhibit no enzyme activity. The GT64 domain in EXTL3 appears to have both GlcNAc transferase I and II activities. However, the possibility remains that the GT47 domain in EXTL3 may catalyze the GlcNAc transferase I reaction, i.e., the first transfer of a GlcNAc residue to the tetrasaccharide linkage region, initiating HS polysaccharide formation.

The conformation of the EXTL3 protein was recently characterized [32]. Awad et al. prepared the human EXTL3 protein without the sequence for the N-terminal cytosolic and transmembrane regions (EXTL3 $\triangle \mathrm{N})$ and examined its stability and conformation. It was stable, with a high temperature needed to denature it. EXTL3 $\Delta \mathrm{N}$ has two $\mathrm{N}$-glycans at Asn290 and Asn592. These are important for proper folding and secretion. The three-dimensional structure of EXTL3 $\Delta \mathrm{N}$ was examined using circular dichroism spectroscopy as well as solution small-angle $\mathrm{X}$-ray scattering and dynamic light scattering. An extended structure consisting of two distinct regions was revealed, which was 


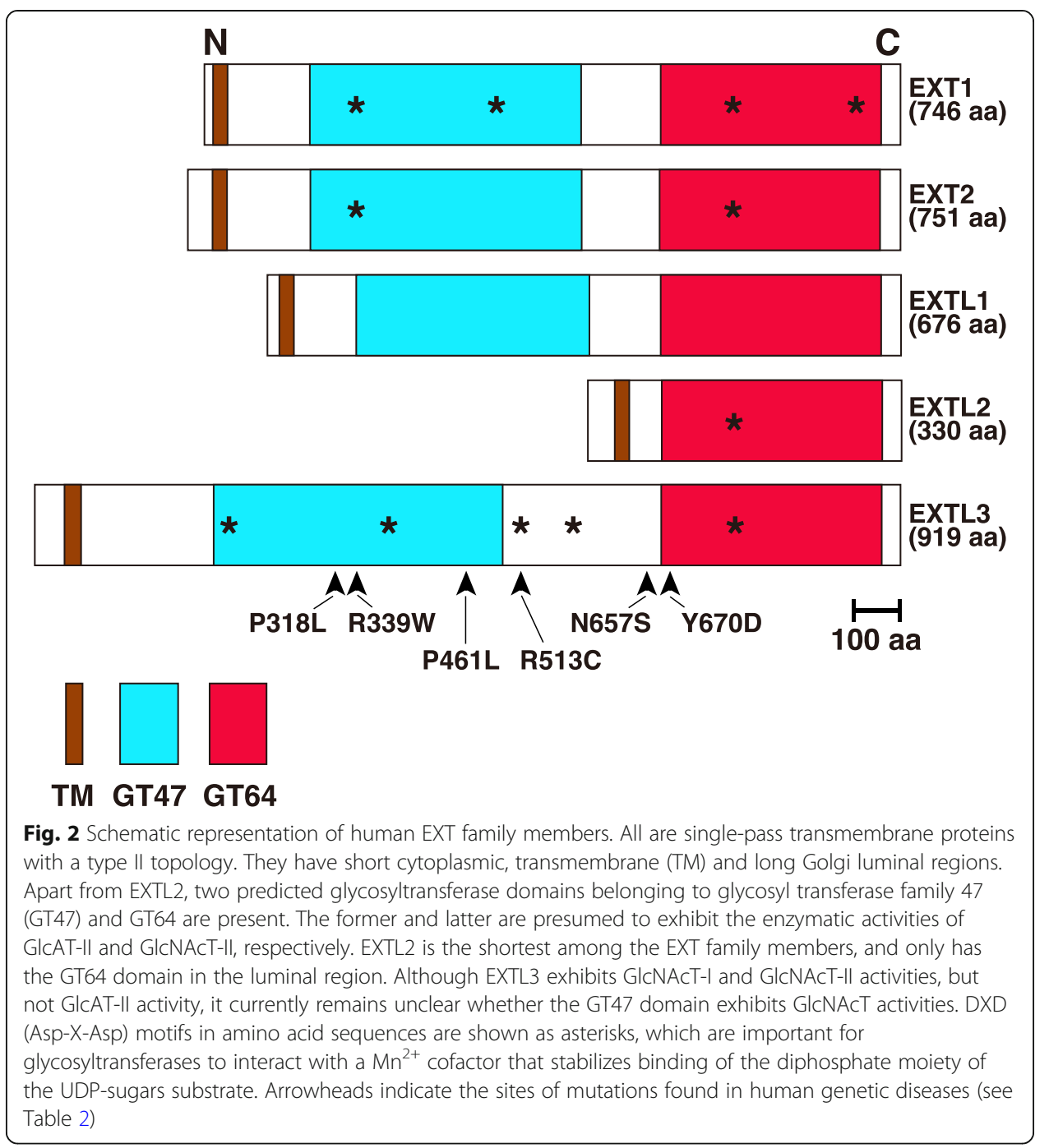

consistent with the bioinformatics data that suggest the presence of two glycosyltransferase domains.

\section{Analysis of Extl3-deficient mice}

Conventional Extl3-deficient mice have been generated using the gene-targeting method. They were embryonically lethal at approximately 9 days post-coitum (dpc) (Table 2) [24]. HS was not synthesized in the embryos. Since difficulties have been associated with elucidating the tissue-specific functions of Extl3 due to the embryonic lethality of systemic Extl3-knockout mice, Extl3-floxed mice with two loxP sequences flanking exon 2 of the Extl3 gene were generated. Some tissue-specific Extl3-deficient mice have been prepared using the Cre-lox recombination approach. Takahashi et al. created pancreatic $\beta$-cell-specific Extl3-knockout mice by mating Extl3-floxed mice with mice harboring the Cre transgene under the control of the rat insulin 2 promoter [24]. These mice had an abnormal islet morphology with reduced $\beta$-cell proliferation and glucose intolerance due to defective insulin secretion (Table 2), indicating the 
Table 2 Loss of function mutations in EXTL3 gene

\begin{tabular}{|c|c|c|}
\hline Mutations & Phenotypes/Clinical Features & Reference \\
\hline $\begin{array}{l}\text { Systemic Ext|3-deficient } \\
\text { mouse }\end{array}$ & $\begin{array}{l}\text { Embryonic lethality }(9 \mathrm{dpc}) \text {. No detectable HS by high performance } \\
\text { liquid chromatography (HPLC) analysis. }\end{array}$ & {$[24]$} \\
\hline $\begin{array}{l}\text { Pancreatic } \beta \text {-cell-specific } \\
\text { Ext|3- deficient mice }\end{array}$ & $\begin{array}{l}\text { Impaired postnatal islet maturation. Reduced HS level by } \\
\text { immunostaining using an anti-HS antibody (3G10). }\end{array}$ & [24] \\
\hline $\begin{array}{l}\text { Podocyte-specific Ext|3- } \\
\text { deficient mice }\end{array}$ & $\begin{array}{l}\text { Irregularities in the glomerular basement membrane and effacement } \\
\text { of the foot processes. No increase in urinary albumin excretion. } \\
\text { Reduced HS level by immunostaining using an anti-HS antibody, } \\
\text { HS4C3, which recognizes the 3-O-sulfated domains of HS. } \\
\text { HS4C3 (1:10), which especially binds to }\end{array}$ & {$[28]$} \\
\hline $\begin{array}{l}\text { Mutations in human EXTL3 } \\
\text { c.1382C }>\text { T (p.Pro461Leu) }\end{array}$ & $\begin{array}{l}\text { Lumbar gibbus, kyphoscoliosis, cervical malformations, hypoplastic } \\
\text { odontoid peg with cervical instability, epiphyseal abnormalities, and } \\
\text { intellectual disability. HS concentration decreased in the urine and } \\
\text { serum, while was normal level in fibroblasts. }\end{array}$ & {$[29]$} \\
\hline c.1537C > T (p.Arg513Cys) & $\begin{array}{l}\text { Short stature, metaphyseal abnormalities of the long bones, early } \\
\text { death, a lack of T cells, and liver cysts. HS concentration decreased in } \\
\text { fibroblasts, while was normal level in the urine and serum. }\end{array}$ & [29] \\
\hline c.1970A > G (p.Asn657Ser) & $\begin{array}{l}\text { Cervical malformations, hypoplastic odontoid peg with cervical } \\
\text { instability, metaphyseal abnormalities of the long bones, early death, } \\
\text { idiopathic CD4 }{ }^{+} \text {lymphopenia, absolute lack of naive T cells, a typical } \\
\text { skin rash, and liver cysts. HS concentration decreased in fibroblasts. }\end{array}$ & [29] \\
\hline c.2008 T > G (p.Tyr670Asp) & $\begin{array}{l}\text { Short stature, epiphyseal abnormalities, intellectual disability, a lack of } \\
\mathrm{T} \text { cells, and a typical skin rash. HS concentration decreased in } \\
\text { fibroblasts as well as the urine and serum. }\end{array}$ & [29] \\
\hline c.1015C > T (p.Arg339Trp) & $\begin{array}{l}\text { Generalized platyspondyly with an increased intervertebral space, } \\
\text { narrow sarco-ischiatic notches with a trident-shaped acetabula, and } \\
\text { short and plump lim bones, metacarpals, and phalanges. Premature } \\
\text { craniosynostosis. Narrowing of the cervical canal and severe narrow- } \\
\text { ing of the laryngotracheal tract. Opisthotonus, hyperreflexia, and gen- } \\
\text { eralized seizures. Developmental delay, clonic arm movements, and } \\
\text { nystagmus. Severe T-cell immunodeficiency. Loger HS chains with an } \\
\text { aberrant sulfation pattern. This mutation does not affect the expres- } \\
\text { sion level of EXTL3 proteins in fibroblasts. }\end{array}$ & {$[30]$} \\
\hline c.1382C > T (p.Pro461Leu) & $\begin{array}{l}\text { Generalized platyspondyly with an increased intervertebral space, } \\
\text { narrow sarco-ischiatic notches with a trident-shaped acetabula, and } \\
\text { short and thick limb bones, metacarpals, and phalanges. Narrowing of } \\
\text { the cervical canal. Muscular hypotonia and marked developmental } \\
\text { delay. Severe T-cell immunodeficiency. This mutation does not affect } \\
\text { the expression level of EXTL3 proteins in peripheral blood mono- } \\
\text { nuclear cells. }\end{array}$ & {$[30]$} \\
\hline c.953C > T (p.Pro318Leu) & $\begin{array}{l}\text { Severe platyspondyly, kyphoscoliosis, pelvic distortion, constriction of } \\
\text { the proximal femora, and brachydactyly. Glycosyltransferase activity of } \\
\text { EXTL3 significantly decreased. This mutation does not affect protein } \\
\text { stability of EXTL3. }\end{array}$ & [31] \\
\hline
\end{tabular}

importance of HS or Extl3 in the regulation of postnatal islet maturation and normal insulin secretion.

Podocyte-specific Extl3-deficient mice have also been generated by crossing Extl3floxed mice with mice expressing Cre recombinase under the control of the nephrin gene (Npsh1) promoter [28]. These mice showed significantly reduced HS levels in the glomerular basement membrane with an abnormal morphology (Table 2). However, urinary albumin excretion was not enhanced, indicating that the involvement of HS in the glomerular charge barrier was smaller than expected. Since other kidney cells synthesize HS, the functions of the glomerular filter barrier may be compensated by other HS-proteoglycans secreted by the surrounding cells. Further studies are needed to clarify the major negative charges of the kidney glomerulus. 
We generated two Extl3-deficient mouse lines: glutamatergic neuron-specific using Cre recombinase under the control of the $\mathrm{Ca}^{2+} /$ calmodulin-dependent protein kinase II gene promoter; and T-cell-specific using Cre recombinase under the control of the lymphocyte-specific protein tyrosine kinase gene promoter (unpublished results). Their phenotypes are currently being investigated.

\section{Novel function of EXTL3 as a cell surface receptor}

As described above, EXTL3 functions as a GlcNAc transferase and is essential for the biosynthesis of HS. This has been established based in various studies using cellular and mouse models. Although the meanings have not been fully elucidated, EXTL3 seems to function as a cell surface receptor.

Kobayashi et al. identified Extl3 as a cell surface receptor of rat regenerating isletderived (Reg) 1 protein, [33], which is an ortholog of human REG1A and REG1B. The Reg family comprises four groups of proteins: Reg1, Reg2, Reg3 and Reg4 [34]. REG1A and REG1B are expressed in humans, while Reg1 is expressed in rodents. There is no human ortholog of mouse Reg2. The Reg3 group includes the rodent Reg3a, Reg3b, Reg3g and Reg3d, and the human REG3A and REG3B. Rodent Reg4 or human REG4 have the lowest similarity with any other rodent or human Reg proteins.

Reg1 protein was initially discovered in regenerating islets of the pancreas. It has been shown to stimulate islet $\beta$-cell growth [35]. Some Reg family members are expressed in the gastrointestinal tract, brain, liver and skin, and they are implicated in cancer, inflammation or tissue injury. The signal of the Reg1 protein was reported to be mediated by cell surface EXTL3 [33].

When EXTL3 catalyzes the reaction for HS biosynthesis, it needs to be located at the Golgi apparatus. However, Kobayashi et al. showed that the cellular distribution of Extl3 was on the cell surface [33]. The overexpression of Extl3 in the rat insulinomaderived $\beta$-cell line RINm5F increased its cell proliferation in response to a Reg1 protein, suggesting that Reg1 protein-dependent signaling is enhanced by the strongly expressed receptor Extl3 [33]. The expression of phosphorylated ERK and phosphorylated AKT was previously shown to be enhanced by stimulation with REG1A in HUVECs, indicating that the signaling pathway involving ERK and AKT was activated by REG1A via the EXTL3 receptor [36].

Most Reg1 studies have been performed using pancreatic cells, but it is also expressed in the central nervous system and its expression is developmentally regulated [37]. Acquatella-Tran Van Ba et al. examined the expression of the Extl3 protein in PC12 neuronal cells and $\beta 3$-tubulin-positive rat hippocampal neurons using immunofluorescence, showing that it was mainly localized in the Golgi apparatus, but also co-localized with Reg1 protein at the plasma membranes of cell bodies and neurites [38]. Although the overexpression of Extl3 alone in PC12 cells did not modify the number of cells with longer neurites, adding Reg1 led to a 2-fold increase in the number of cells with longer neurites. This suggests that Reg1 effects on neurite outgrowth are mediated through its receptor Extl3. Furthermore, the proportion of cells with longer neurites was significantly smaller following the downregulation of Extl3 by shRNA than when the control non-effective shRNA was used.

The role of EXTL3 in Reg1-signaling has yet to be sufficiently demonstrated [34]. Direct interaction between Reg1 and AExtl3 has not been shown conclusively via 
immunoprecipitation or other methods. Although Mueller et al. performed a yeast twohybrid analysis to find the binding partners of rat Reg1, the identified clones did not show homology with the Extl3 gene [39]. Kadowaki et al. reported that EXTL3 does not seem to act upstream of kinases believed to be targeted by Reg1 [40]. Most importantly, a role of EXTL3 in intracellular signaling has never been confirmed. Although Mizuno et al. suggested that EXTL3 induces the NF-кB signaling through stimulation with TNF- $\alpha$ [41], a link between Reg1 and this signaling pathway has never been established. Therefore, evidence of a function for EXTL3 in Reg1 signaling is not only inconclusive but even conflicting.

The involvement of EXTL3 in the signaling of other Reg proteins has also been reported. Levetan et al. identified EXTL3 as a REG3A-binding protein on the cell surface and demonstrated that REG3A enhances EXTL3 translocation from the membrane to the nucleus [42]. Lai et al. demonstrated that REG3A is abundantly expressed in the epidermal keratinocytes of psoriasis patients and promotes wound re-epithelialization and psoriatic hyperproliferation [43]. Silencing EXTL3 inhibited the effects of REG3A on cell proliferation and differentiation. Furthermore, an antibody against EXTL3 abrogated the activity of REG3A. However, EXTL3 silencing did not decrease the effects of fibroblast growth factor 7, which requires $\mathrm{HS}$ as a co-receptor, indicating that REG3A acts through EXTL3 as its functional receptor expressed on the cell surface of keratinocytes independent of its glycosyltransferase activity.

Lai et al. also identified the downstream signaling molecule of EXTL3 as phosphatidylinositol 3-kinase (PI3K). REG3A was shown to activate the EXTL3-PI3K-AKT signaling pathway to regulate keratinocyte proliferation and/or differentiation [43]. However, the role of EXTL3 in REG3A signaling is also debatable [34]. The amount of HS on the keratinocyte cell surface and in the wound environment is very low, but the predominant glycosaminoglycan in the skin is dermatan sulfate, which can act as a coreceptor for fibroblast growth factor 7 [44]. Blocking EXTL3 did not affect REG3Ainduced cell proliferation [45].

Epidermal growth factor receptor (EGFR) has been reported to be another candidate for the receptor for REG3A. Immunostaining showed that EGFR and REG3A can colocalize on SW1990 pancreatic adenocarcinoma cells and their complex could be detected using co-immunoprecipitation. The REG3A-enhanced expression of the cell cycle regulatory switch cyclin D1 could be negated by treatment with an EGFR inhibitor, suggesting the involvement of EGFR in REG3A signaling [45].

The involvement of EXTL3 in endometriosis, a benign chronic condition characterized by the existence of endometrial-like stroma and glandular tissue in extrauterine locations, was recently reported [46]. Unidentified factor(s) in the serum of patients interacted with EXTL3, resulting in increased colony formation in regenerating cell cultures. Although REG proteins were not examined in that study, EXTL3 may play a role in endometriosis as a membrane signaling molecule that interacts with these ligands. However, cell surface HS synthesized by EXTL3 may regulate the cell entry of viruses, potentially contributing to the pathogenesis of endometriosis.

\section{Congenital diseases caused by mutations in the human EXTL3 gene}

Genetic diseases caused by biallelic mutations in the EXTL3 gene have been reported. Oud et al. found that homozygous missense mutations in EXTL3, including c.1382C > 
T (p.Pro461Leu), c.1537C > T (p.Arg513Cys), c.1970A > G (p.Asn657Ser) and c.2008 $\mathrm{T}>\mathrm{G}$ (p.Tyr670Asp), resulted in a neuro-immuno-skeletal dysplasia syndrome [29]. Affected individuals presented with various skeletal abnormalities and neurodevelopmental defects. Some patients also showed severe combined immunodeficiency with a complete absence of $\mathrm{T}$ cells (Table 2). All four mutations were located in the luminal region, with the former two mutations and latter two near or inside the GT47 and GT64 domains, respectively (Fig. 2). The concentration of HS was lower in the fibroblasts of affected individuals, except for those from a patient with a homozygous missense mutation of c.1382C $>\mathrm{T}$ (p.Pro461Leu). The catalytic activities of GlcNAc transferases I and II in mutated EXTL3 proteins have not yet been assessed.

Volpi et al. also examined patients with severe skeletal dysplasia, T-cell immunodeficiencies and developmental delays (Table 2) [30]. The homozygous missense mutations in the EXTL3 gene, c.1015C > T (p.Arg339Trp) and c.1382C > T (p.Pro461Leu), have been implicated in the pathogenesis of this disease. These two mutations are both located in the glycosyltransferase domain GT47. Abnormalities were detected in the production of HS by the fibroblasts of patients. However, the catalytic activities of GlcNAc transferases in mutated EXTL3 proteins have not yet been investigated.

We previously reported a novel type of spondylo-epi-metaphyseal dysplasia caused by biallelic EXTL3 mutations [31]. Anomalies were observed in the spine, epiphyses and metaphyses of patients (Table 2). The mutation identified in the EXTL3 gene was c.953C > T (p.Pro318Leu). It differed from those reported previously. The substituted residue in EXTL3 is highly conserved among diverse species [9]. We examined the GlcNAc tansferase II activity of the EXTL3 missense variant. The recombinant mutant protein exhibits markedly weaker activity than the wild-type enzyme, suggesting that the mutation reduces enzyme activity.

Based on the findings obtained from 14 patients from nine unrelated families, the phenotypic spectrum of the disease may now be defined [47]. Critical features are severe platyspondyly, brachydactyly and kyphoscoliosis. The majority of patients present with facial dysmorphisms, with upslanting palpebral fissures, frontal bossing, a prominent nose and a broad nasal tip. Truncal hypotonia and severe motor development delays are commonly observed. Some patients have a history of seizures and liver and kidney cysts. Several patients had T-cell lymphopenia, Omenn syndrome or eosinophilia, indicating that immune dysregulation is part of the phenotype of this disease. It currently remains unknown whether these phenotypes are due to abnormalities in the structure of HS and/or the receptor function of EXTL3.

\section{Concluding remarks}

Several issues have yet to be resolved in studies on the EXTL3 protein. The role of EXTL3 in the biosynthesis of HS remains unclear. Although EXTL3 is considered to play a role in the initiation reaction of the biosynthesis of HS [22], this process does not appear to be inhibited at the transfer of the first GlcNAc residue in Extl3-deficient mice. This is because the phenotype of Ext1- or Ext2-deficient mice is more severe than that of Extl3-deficient mice. Both mice exhibit embryonic lethality, with Ext1- or Ext2deficient mice and Extl3-deficient mice dying at 7.5 [48, 49] and 9 dpc [24], respectively. Weak and incomplete compensation by other glycosyltransferases such as Extl2 may prolong the survival of Extl3-deficient mice. However, these glycosyltransferases 
have not yet been identified. Therefore, the structures of presumably truncated HS chains synthesized by Extl3-deficient mice need to be elucidated.

The active domains for GlcNAc transferases in EXTL3 currently remain unknown. There are two predicted glycosyltransferase domains: GT47 and GT64 (Fig. 2). Based on previous studies on EXT1 [50], the GT64 domain is predicted to exhibit the activity of GlcNAc transferase II. However, it has not yet been established whether the GT47 domain in EXTL3 exhibits enzymatic activity, if this is GlcNAc transferase I activity, or whether the GT64 domain exhibits both GlcNAc transferase I and II activities. Therefore, further characterization of this enzyme is required. Mutations in EXTL3 of the patient were found in the GT47 domain (Fig. 2), which is the predicted GlcA transferase II domain and may have no enzyme activity. However, HS concentrations were shown to be lower in some cases (Table 2).

Although EXTL3 functions as a receptor molecule, it has not yet been characterized in sufficient detail. More detailed structural information on the binding sites for ligands is needed, and the transduction of intracellular signaling warrants further study.

It is not clear whether symptoms of the diseases caused by mutations in the human EXTL3 gene are due to the lack of HS or a deficiency in the cellular signaling of REG proteins through the EXTL3 receptor. This is because the GlcNAc transferase I activity of the mutated EXTL3 proteins has not been examined. In some cases, the level of HS in patient fibroblasts is not affected. Structural studies on HS in patients have been insufficient, but are essential for clarifying the underlying pathogenic mechanisms. A detailed characterization of Extl3-deficient mice may also resolve these issues.

Abbreviations

EXT: Exostosin; EXTL: Exostosin-like; HS: Heparan sulfate; Gal: D-galactose; GlcA: D-glucuronic acid; GlcNAc: N-acetyl-Dglucosamine; IdoA: L-iduronic acid; Xyl: Xylose; REG: Regenerating islet-derived; UDP: Uridine diphosphate

Acknowledgments

I would like to thank Dr. Shuji Mizumoto (Meijo University) for helping me to prepare Figs. 1 and 2.

Author's contributions

I conceived the subject matter and wrote this review. The author(s) read and approved the final manuscript.

\section{Funding}

This study was supported in part by the Grant-in-Aid for Scientific Research (C) 18 K06670 from the Japanese Society for the Promotion of Science (JSPS) and the Grant-in-Aid for the Research Center for Pathogenesis of Intractable Diseases from the Research Institute of Meijo University.

Availability of data and materials

Not applicable.

Ethics approval and consent to participate

Not applicable.

Consent for publication

Not applicable.

Competing interests

Not applicable.

Received: 18 April 2020 Accepted: 11 August 2020

Published online: 20 August 2020

References

1. Wicklund CL, Pauli RM, Johnson DR, Hecht JT. Natural history of hereditary multiple exostoses. Am J Med Genet. 1995; 55(1):43-6.

2. Schmale GA, Conrad EU, Raskind WH. The natural history of hereditary multiple exostoses. J Bone Joint Surg Am. 1994; 76(7):986-92. 
3. Pacifici M. The pathogenic roles of heparan sulfate deficiency in hereditary multiple exostoses. Matrix Biol. 2018;71-72: 28-39.

4. Cook A, Raskind W, Blanton SH, Pauli RM, Gregg RG, Francomano CA, et al. Genetic heterogeneity in families with hereditary multiple exostoses. Am J Hum Genet. 1993;53(1):71-9.

5. Le Merrer M, Legeai-Mallet L, Jeannin PM, Horsthemke B, Schinzel A, Plauchu H, et al. A gene for hereditary multiple exostoses maps to chromosome 19p. Hum Mol Genet. 1994;3(5):717-22.

6. Wu YQ, Heutink P, de Vries BB, Sandkuijl LA, van den Ouweland AM, Niermeijer MF, et al. Assignment of a second locus for multiple exostoses to the pericentromeric region of chromosome 11. Hum Mol Genet. 1994;3(1):167-71.

7. Lind T, Tufaro F, McCormick C, Lindahl U, Lidholt K. The putative tumor suppressors EXT1 and EXT2 are glycosyltransferases required for the biosynthesis of heparan sulfate. J Biol Chem. 1998;273(41):26265-8.

8. McCormick C, Leduc Y, Martindale D, Mattison K, Esford L, Dyer A, Tufaro F. The putative tumour suppressor EXT1 alters the expression of cell-surface heparan sulfate. Nat Genet. 1998;19(2):158-61.

9. Busse-Wicher M, Wicher KB, Kusche-Gullberg M. The exostosin family: proteins with many functions. Matrix Biol. 2014;35:25-33.

10. Wise CA, Clines GA, Massa H, Trask BJ, Lovett M. Identification and localization of the gene for EXTL, a third member of the multiple exostoses gene family. Genome Res. 1997;7(1):10-6.

11. Wuyts W, Van Hul W, Hendrickx J, Speleman F, Wauters J, De Boulle K, et al. Identification and characterization of a novel member of the EXT gene family, EXTL2. Eur J Hum Genet. 1997;5(6):382-9.

12. Van Hul W, Wuyts W, HendrickX J, Speleman F, Wauters J, De Boulle K, et al. Identification of a third EXT-like gene (EXTL3) belonging to the EXT gene family. Genomics. 1998;47(2):230-7.

13. Kim BT, Kitagawa H, Tamura J, Saito T, Kusche-Gullberg M, Lindahl U, Sugahara K. Human tumor suppressor EXT gene family members EXTL1 and EXTL3 encode alpha 1,4- N-acetylglucosaminyltransferases that likely are involved in heparan sulfate/ heparin biosynthesis. Proc Natl Acad Sci U S A. 2001;98(13):7176-81.

14. Okada M, Nadanaka S, Shoji N, Tamura J, Kitagawa H. Biosynthesis of heparan sulfate in EXT1-deficient cells. Biochem J. 2010;428(3):463-71.

15. Conrad HE. Heparin-Binding Proteins. San Diego: Academic Press; 1998

16. Xu D, Esko JD. Demystifying heparan sulfate-protein interactions. Annu Rev Biochem. 2014;83:129-57.

17. Kreuger J, Kjellén L. Heparan sulfate biosynthesis: regulation and variability. J Histochem Cytochem. 2012;60(12):898-907.

18. Busse M, Kusche-Gullberg M. In vitro polymerization of heparan sulfate backbone by the EXT proteins. J Biol Chem. 2003;278(42):41333-7.

19. Kim BT, Kitagawa H, Tanaka J, Tamura J, Sugahara K. In vitro heparan sulfate polymerization: crucial roles of core protein moieties of primer substrates in addition to the EXT1-EXT2 interaction. J Biol Chem. 2003;278(43):41618-23.

20. Stickens D, Brown D, Evans GA. EXT genes are differentially expressed in bone and cartilage during mouse embryogenesis. Dev Dyn. 2000;218(3):452-64.

21. Nadanaka S, Kagiyama S, Kitagawa H. Roles of EXTL2, a member of the EXT family of tumour suppressors, in liver injury and regeneration processes. Biochem J. 2013;454(1):133-45.

22. Busse M, Feta A, Presto J, Wilén M, Grønning M, Kjellén L, Kusche-Gullberg M. Contribution of EXT1, EXT2, and EXTL3 to heparan sulfate chain elongation. J Biol Chem. 2007;282(45):32802-10.

23. Chen YH, Narimatsu Y, Clausen TM, Gomes C, Karlsson R, Steentoft C, et al. The GAGOme: a cell-based library of displayed glycosaminoglycans. Nat Methods. 2018;15(11):881-8.

24. Takahashi I, Noguchi N, Nata K, Yamada S, Kaneiwa T, Mizumoto S, et al. Important role of heparan sulfate in postnatal islet growth and insulin secretion. Biochem Biophys Res Commun. 2009;283(1):113-8.

25. Kusche-Gullberg M, Kjellén L. Sulfotransferases in glycosaminoglycan biosynthesis. Curr Opin Struct Biol. 2003;13(5):605-11.

26. Ringvall M, Kjellén L. Mice deficient in heparan sulfate N-deacetylase/N-sulfotransferase 1. Prog Mol Biol Transl Sci. 2010; 93:35-58.

27. Nadanaka S, Purunomo E, Takeda N, Tamura J, Kitagawa H. Heparan sulfate containing unsubstituted glucosamine residues: biosynthesis and heparanase-inhibitory activity. J Biol Chem. 2014;289(22):15231-43.

28. Aoki S, Saito-Hakoda A, Yoshikawa T, Shimizu K, Kisu K, Suzuki S, et al. The reduction of heparan sulphate in the glomerular basement membrane does not augment urinary albumin excretion. Nephrol Dial Transplant. 2018:33(1):26-33.

29. Oud MM, Tuijnenburg P, Hempel M, van Vlies N, Ren Z, Ferdinandusse S, et al. Mutations in EXTL3 cause neuroimmuno-skeletal dysplasia syndrome. Am J Hum Genet. 2017;100(2):281-96.

30. Volpi S, Yamazaki Y, Brauer PM, van Rooijen E, Hayashida A, Slavotinek A, et al. EXTL3 mutations cause skeletal dysplasia, immune deficiency, and developmental delay. J Exp Med. 2017;214(3):623-37.

31. Guo L, Elcioglu NH, Mizumoto S, Wang Z, Noyan B, Albayrak HM, et al. Identification of biallelic EXTL3 mutations in a novel type of spondylo-epi-metaphyseal dysplasia. J Hum Genet. 2017;62(8):797-801.

32. Awad W, Kjellström S, Svensson Birkedal G, Mani K, Logan DT. Structural and biophysical characterization of human EXTL3: domain organization, glycosylation, and solution structure. Biochemistry. 2018;57(7):1166-77.

33. Kobayashi S, Akiyama T, Nata K, Abe M, Tajima M, Shervani NJ, et al. Identification of a receptor for reg (regenerating gene) protein, a pancreatic beta-cell regeneration factor. J Biol Chem. 2000;275(15):10723-6.

34. Chen Z, Downing S, Tzanakakis ES. Four decades after the discovery of regenerating islet-derived (Reg) proteins: current understanding and challenges. Front Cell Dev Biol. 2019;7:235.

35. Terazono K, Yamamoto H, Takasawa S, Shiga K, Yonemura Y, Tochino Y, Okamoto H. A novel gene activated in regenerating islets. J Biol Chem. 1988;263(5):2111-4.

36. Hara K, Fukui H, Sun C, Kitayama Y, Eda H, Yamasaki T, et al. Effect of REG la protein on angiogenesis in gastric cancer tissues. Oncol Rep. 2015;33(5):2183-9.

37. de la Monte SM, Ozturk M, Wands JR. Enhanced expression of an exocrine pancreatic protein in Alzheimer's disease and the developing human brain. J Clin Invest. 1990;86(3):1004-13.

38. Acquatella-Tran Van Ba I, Marchal S, François F, Silhol M, Lleres C, Michel B, et al. A. Regenerating islet-derived 1a (Reg1a) protein is new neuronal secreted factor that stimulates neurite outgrowth via exostosin tumor-like 3 (EXTL3) receptor. J Biol Chem 2012;287(7):4726-4739.

39. Mueller CM, Zhang H, Zenilman ME. Pancreatic reg I binds MKP-1 and regulates cyclin D in pancreatic-derived cells. J Surg Res. 2008;150(1):137-43. 
40. Kadowaki Y, Ishihara S, Miyaoka Y, Rumi MA, Sato H, Kazumori H, et al. Reg protein is overexpressed in gastric cancer cells, where it activates a signal transduction pathway that converges on ERK1/2 to stimulate growth. FEBS Lett. 2002; 530(1-3):59-64.

41. Mizuno K, Irie S, Sato TA. Overexpression of EXTL3/EXTR1 enhances NF-kappaB activity induced by TNF-alpha. Cell Signal. 2001;13(2):125-30.

42. Levetan CS, Upham LV, Deng S, Laury-Kleintop L, Kery V, Nolan R, et al. Discovery of a human peptide sequence signaling islet neogenesis. Endocr Pract. 2008;14(9):1075-83.

43. Lai Y, Li D, Li C, Muehleisen B, Radek KA, Park HJ, et al. The antimicrobial protein REG3A regulates keratinocyte proliferation and differentiation after skin injury. Immunity. 2012;37(1):74-84.

44. Trowbridge JM, Rudisill JA, Ron D, Gallo RL. Dermatan sulfate binds and potentiates activity of keratinocyte growth factor (FGF-7). J Biol Chem. 2002;277(45):42815-20.

45. Liu X, Wang J, Wang H, Yin G, Liu Y, Lei X, Xiang M. REG3A accelerates pancreatic cancer cell growth under IL-6associated inflammatory condition: involvement of a REG3A-JAK2/STAT3 positive feedback loop. Cancer Lett. 2015; 362(1):45-60

46. Aints A, Mölder S, Salumets A. EXTL3-interacting endometriosis-specific serum factors induce colony formation of endometrial stromal cells. Sci Rep. 2019;9(1):12562.

47. Notarangelo LD. Expanding the spectrum of skeletal dysplasia with immunodeficiency: a commentary on identification of biallelic EXTL3 mutations in a novel type of spondylo-epi-metaphyseal dysplasia. J Hum Genet. 2017;62(8):737-8.

48. Lin X, Wei G, Shi Z, Dryer L, Esko JD, Wells DE, Matzuk MM. Disruption of gastrulation and heparan sulfate biosynthesis in EXT1-deficientmice. Dev Biol. 2000;224(2):299-311.

49. Stickens D, Zak BM, Rougier N, Esko JD, Werb Z. Mice deficient in Ext2 lack heparan sulfate and develop exostoses. Development. 2005;132(22):5055-68.

50. Wei G, Bai X, Gabb MM, Bame KJ, Koshy TI, Spear PG, Esko JD. Location of the glucuronosyltransferase domain in the heparan sulfate copolymerase EXT1 by analysis of Chinese hamster ovary cell mutants. J Biol Chem. 2000;275(36):2773340 .

\section{Publisher's Note}

Springer Nature remains neutral with regard to jurisdictional claims in published maps and institutional affiliations.

\section{Ready to submit your research? Choose BMC and benefit from:}

- fast, convenient online submission

- thorough peer review by experienced researchers in your field

- rapid publication on acceptance

- support for research data, including large and complex data types

- gold Open Access which fosters wider collaboration and increased citations

- maximum visibility for your research: over $100 \mathrm{M}$ website views per year

At $\mathrm{BMC}$, research is always in progress. 